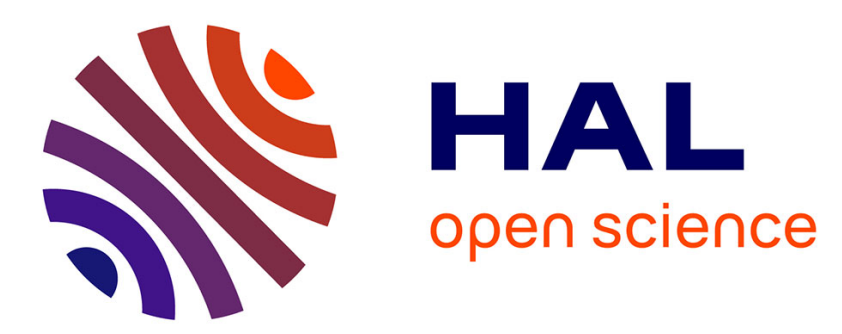

\title{
Structure and Magnetic Properties of Polycrystalline Y3-xLaxFe5O12 Garnets
}

\author{
Y. Song, S. Yu, W. Kim, S. Yip Lee, T. Choy
}

\section{To cite this version:}

Y. Song, S. Yu, W. Kim, S. Yip Lee, T. Choy. Structure and Magnetic Properties of Polycrystalline Y3-xLaxFe5O12 Garnets. Journal de Physique IV Proceedings, 1997, 07 (C1), pp.C1-445-C1-446. 10.1051/jp4:19971180 . jpa-00254829

\section{HAL Id: jpa-00254829 https://hal.science/jpa-00254829}

Submitted on 1 Jan 1997

HAL is a multi-disciplinary open access archive for the deposit and dissemination of scientific research documents, whether they are published or not. The documents may come from teaching and research institutions in France or abroad, or from public or private research centers.
L'archive ouverte pluridisciplinaire HAL, est destinée au dépôt et à la diffusion de documents scientifiques de niveau recherche, publiés ou non, émanant des établissements d'enseignement et de recherche français ou étrangers, des laboratoires publics ou privés. 


\title{
Structure and Magnetic Properties of Polycrystalline $Y_{3-x} \mathrm{La}_{x} \mathrm{Fe}_{5} \mathrm{O}_{12}$ Garnets
}

\author{
Y.Y. Song, S.C. Yu, W.T. Kim*, S.S. Lee** and T.G. Choy** \\ Department of Physics, Chungbuk National University Cheongju, 360-763 Korea \\ * Department of Physics, Chongju University Chongju, 360-764 Korea (RASOM) \\ **Component Technology Section, ETRI, Taejeon, 305-600 Korea
}

\begin{abstract}
La substituted polycrystalline $\mathrm{Y}_{3-x} \mathrm{La}_{x} \mathrm{Fe}_{5} \mathrm{O}_{12}(\mathrm{x}=0.0-0.5)$ garnets were manufactured by ceramic method and the structure and magnetic properties of the garnets were studied by $X$-ray diffractometry, magnetometry, ferromagnetic resonance and permittivity and permeability measurement. Saturation magnetization and Curie temperature of the garnets increase slightly with increasing La content. Resonance linewidth decreases with increasing La concentration $x$. Complex permittivity and permeability of the garnets are reported.
\end{abstract}

\section{I . INTRODUCTION}

YIG has been widely used because of its small resonance linewidth in many devices such as isolator, circulator and gyrators[1-2]. The saturation magnetization, gyromagnetic resonance linewidth, microwave penneability and permittivity are properties which are of fundamental importance in determining the performance of the devices in the microwave region. Several types of substituted magnetic garnets for high frequency applications were developed to tailor and to improve their magnetic and microwave properties recently.

In this paper, we have investigated the structure and magnetic properties of $\mathrm{La}$ substituted polycrystalline $\mathrm{Y}_{3-x} \mathrm{La}_{x} \mathrm{Fe}_{5} \mathrm{O}_{12}(\mathrm{x}=0.0,0.1,0.2,0.3,0.4,0.5)$ garnets. Futhermore, we have measured magnetic resonance linewidth $(\Delta \mathrm{H})$, microwave permittivity and permeability in microwave range.

\section{II . EXPERIMENT}

Polycrystalline $\mathrm{Y}_{3-x} \mathrm{La}_{\mathrm{x}} \mathrm{Fe}_{5} \mathrm{O}_{12}$ samples were prepared by conventional ceramic method. Mixed high purity $\mathrm{Y}_{2} \mathrm{O}_{3}$, $\mathrm{La}_{2} \mathrm{O}_{3}$ and $\mathrm{Fe}_{2} \mathrm{O}_{3}$ powders were fired at $1200{ }^{\circ} \mathrm{C}$ for $2 \mathrm{hrs}$ and then sintered at $1400{ }^{\circ} \mathrm{C}$ for 2 hrs in the air. For structural characterization of the resulting samples, XRD experiment was carried out with $\mathrm{Cu} \mathrm{K}_{a}$ radiation. Temperature dependence of saturation magnetization of the polycrystalline $\mathrm{Y}_{3-x} \mathrm{La}_{x} \mathrm{Fe}_{5} \mathrm{O}_{12}$ garnets was measured by vibrating sample magnetometry (VSM) from toom temperature to $600 \mathrm{~K}$ with an external field of $5 \mathrm{kOe}$. Ferromagnetic resonance line width $(\Delta \mathrm{H})$ of the polycrystalline garnets was measured at $9.44 \mathrm{GHz}$ by using spherical sample of $0.5 \mathrm{~mm}$ in diameter. Also microwave permittivity and permeability of the polycrystalline garnets were measured by using the cavity perturbation method at $\mathrm{TE}_{101}$ and $\mathrm{TE}_{104}$ mode respectively. The measurement was performed by using rectangular samples of about $0.5 \times 0.7 \times 10.2 \mathrm{~mm}$ in a rectangular cavity.

\section{RESULT AND DISCUSSION}

The experimental condition was found after several pre-experiments. The prepared garnet samples showed densities of about $97 \%$ of $\mathrm{X}$-ray densities. XRD trace from $\mathrm{Y}_{3-\mathrm{x}} \mathrm{La}_{x} \mathrm{Fe}_{5} \mathrm{O}_{12}$ samples showed diffraction peaks corresponding to cubic garnet structure and a weak peak corresponding to perovskite phase, indicating a presence of small amount of perovskite phase. Lattice constant of the cubic structure increased linearly from 12.382 to $12.443 \AA$ with increasing $\mathrm{La}$ from $\mathrm{x}=0.0$ to $\mathrm{x}=0.5$, indicating a formation of homogeneous solid solution. Microstructure of the sample was observed by scanning electron microscopy (SEM). Grain size of the gamet increased from about $8 \mu \mathrm{m}$ to $25 \mu \mathrm{m}$ with increasing La from $x=0.0$ to $x=0.5$. A grain boundary phase was observed in the specimen with high La content $x=0.5$, even though volume fraction is 
too low to be detected by XRD experiment. It was difficult to find a variation in porosity with La content.

Fig. 1 shows temperature dependence of saturation magnetization of the $\mathrm{Y}_{3 \times \times} \mathrm{La}_{x} \mathrm{Fe}_{5} \mathrm{O}_{12}$ garnets as a function of temperature. The saturation magnetization decreased with increasing temperature as expected. The saturation magnetization at room temperature increased slightly from about 1700 to $1780 \mathrm{G}$ with increasing La content from 0 to 0.4. Also the Curie temperature for $\mathrm{Y}_{3 \cdot \times} \mathrm{La}_{x} \mathrm{Fe}_{5} \mathrm{O}_{12}$ garnets increased slightly from about 570 to 576 $\mathrm{K}$. The slight changes in saturation magnetization and Curie temperature with La content may be related with the increase in lattice constant with increasing La content. Because magnetic property of $\mathrm{La}^{3+}$ ion is same as that of $\mathrm{Y}^{3+}$ ion.

Fig 2 shows a variation of ferromagnetic resonance linewidth, $\Delta \mathrm{H}$, with $\mathrm{La}$ content $(\mathrm{x})$ for $\mathrm{Y}_{3-\mathrm{x}} \mathrm{La}_{\mathrm{x}} \mathrm{Fe}_{5} \mathrm{O}_{12}$ sintered at $1400^{\circ} \mathrm{C} . \Delta \mathrm{H}$ is decreased slightly from about $90 \mathrm{Oe}$ to $65 \mathrm{Oe}$ with increasing $\mathrm{x}$ from 0.0 to 0.4 . The decrease seems to be due to the increased grain size with increasing $\mathrm{La}$ content. The large $\Delta \mathrm{H}$ value at $x=0.5$ is due to the presence of grain boundary phase.

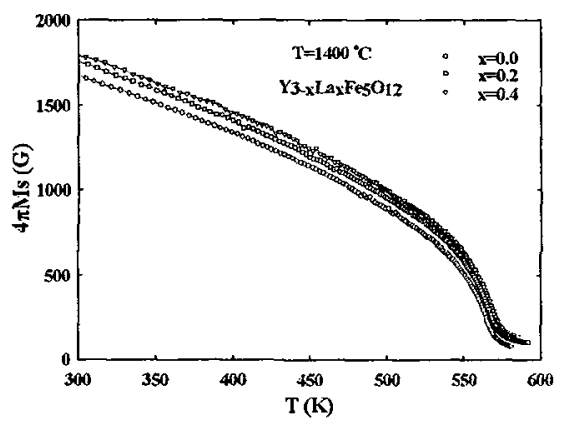

Fig.1 Temperature dependence of saturation magnetization as a function of temperature.

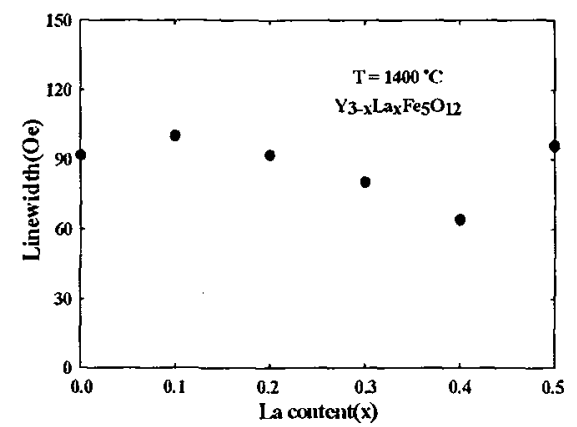

Fig. 2 Ferromagnetic resonance linewidth as a function of $\mathrm{x}$ for sintered $\mathrm{Y}_{3-\mathrm{x}} \mathrm{La}_{x} \mathrm{Fe}_{5} \mathrm{O}_{12}$ at $1400^{\circ} \mathrm{C}$.

Table 1. shows the complex permittivities and permeabilities measured by cavity perturbation method at $\mathrm{TE}_{101}$ and $\mathrm{TE}_{104}$ mode, respectively, for sintered $\mathrm{Y}_{3-x} \mathrm{La}_{x} \mathrm{Fe}_{5} \mathrm{O}_{12}$ at $1400^{\circ} \mathrm{C}$. Permittivity and permeability were measured at $6.8 \mathrm{GHz}$ and $10.0 \mathrm{GHz}$ respectively. It was difficult to find a relationship between $\mathrm{La}$ content and permittivity of the substituted garnet. The values of the $\varepsilon_{\mathrm{r}}$ are in the range of $15.0-17.5$. The value of $\varepsilon \mathrm{J}$ $\varepsilon_{\mathrm{r}}$ of $\mathrm{Y}_{3-\mathrm{x}} \mathrm{La}_{\mathrm{x}} \mathrm{Fe}_{51} \mathrm{O}_{12}$ sample was larger than typical value of $10^{-3}$ in polycrystalline YIG. The real part of the microwave permeability $\mu_{\mathrm{r}}$ was about 1 , which is slightly larger than the value of 0.9 in pure YIG [3]. The imaginary part of the permeability $\mu_{\mathrm{i}}$ varied in the range of $6.5 \times 10^{-3}-51 \times 10^{-3}$.

\begin{tabular}{|c|c|c|c|c|}
\hline $\mathrm{x}$ & $\varepsilon_{\mathrm{r}}$ & $\varepsilon_{\mathrm{i}}$ & $\mu_{\mathrm{r}}$ & $\frac{\mu_{\mathrm{i}}}{}$ \\
\hline 0 & 17.10 & 0.49 & 0.98 & $8.3 \times 10^{-3}$ \\
\hline 0.1 & 16.81 & 0.15 & 1.01 & $7.9 \times 10^{-3}$ \\
\hline 0.2 & 15.76 & 0.28 & 1.01 & $6.5 \times 10^{-3}$ \\
\hline
\end{tabular}

\begin{tabular}{|c|c|c|c|c|}
\hline $\mathrm{x}$ & $\varepsilon_{\mathrm{r}}$ & $\varepsilon_{\mathrm{i}}$ & $\mu_{\mathrm{r}}$ & $\mu_{\mathrm{i}}$ \\
\hline 0.3 & 14.95 & 0.09 & 1.02 & $11.7 \times 10^{-5}$ \\
\hline 0.4 & 15.04 & 0.25 & 1.02 & $39.7 \times 10^{-3}$ \\
\hline 0.5 & 17.54 & 0.80 & 0.98 & $51.2 \times 10^{-3}$ \\
\hline
\end{tabular}

Table 1. Complex permittivity $(\varepsilon)$ and permeability $(\mu)$ measured by cavity perturbation method at $\mathrm{TE}_{101}$ and $\mathrm{TE}_{104}$ mode, respectively for sintered $\mathrm{Y}_{3-\mathrm{x}} \mathrm{La}_{x} \mathrm{Fe}_{5} \mathrm{O}_{12}$ at $1400^{\circ} \mathrm{C}$.

\section{CONCLUSIONS.}

Single phase La substituted polycrystalline $\mathrm{Y}_{3 . \times} \mathrm{La}_{x} \mathrm{Fe}_{5} \mathrm{O}_{12}(x=0.0-0.4)$ garnets were manufactured by ceramic method. Saturation magnetization and Curie temperature of the garnets increased slightly with increasing $\mathrm{La}$ content. Resonance linewidth decreased with increasing La concentration $\mathrm{x}$. Complex permittivity and permeability were measured by cavity perturbation method at $\mathrm{TE}_{101}$ and $\mathrm{TE}_{104}$ mode.

\section{Reference}

[1] P.E Seiden and J.G. Grunberg, J. Appl. Phys., 34 (1963), 1696

[2] R. H. Knerr, IEEE Trans. Microwave Theory Tech., MTT-23 (1975), 818

[3] S. Zhu, H. Chen, F. Wen, Y.Qin and J. Liu, J Appl. Phys., 69 (1991), 6201 